\title{
Fresh Apple And Tomato Prices At Direct Marketing Outlets Versus Competing Retailers In The U.S. Mid-Atlantic Region
}

Steve W. Martinez, Economic Research Service, USA

\begin{abstract}
This study uses Nielsen Homescan panel data to compare average prices of fresh apples and tomatoes purchased at direct-to-consumer outlets (e.g., farmers' markets) with prices at grocery stores and supercenters in the Mid-Atlantic region. Compared to grocery stores, prices at direct sales outlets are estimated to be lower, on average, for both tomatoes and apples. Tomato prices at direct sales outlets were also less than supercenter prices in all seasons and subregions. Apple prices paid by consumers at direct sales outlets were comparable to prices paid at supercenters, except for the Maryland/Delaware/New Jersey subregion, where direct sales outlet prices were markedly lower.
\end{abstract}

Keywords: Direct-To-Consumer Outlets; Farmers’ Markets; Prices; Nielsen Homescan Panel Data

\section{INTRODUCTION}

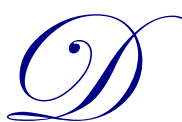

irect-to-consumer sales outlets (farmers' markets, roadside stands, onfarm stores, farmers' markets, pick-your-own sites) are linked to demand for locally-grown food. A 2006 USDA farmers' market manager survey found that freshness, taste, and access to locally-grown food were the top three reasons that managers believed consumers shopped at their markets (Ragland and Tropp, 2009). Other studies have found that the main reasons consumers shop at farmers' markets is for local production among other factors, including the shopping atmosphere, environmental consciousness, product freshness, appearance, and variety (Gao et al., 2012; Onianwa et al., 2006).

Perceptions about prices at direct sales outlets versus competing retail food outlets vary widely. Higher prices at direct sales outlets may serve as a barrier to greater patronage of these venues (Claro, 2011; Chambers et al., 2007). Local food advocates suggest that farmers who market through direct sales venues can receive greater returns for their products compared to conventional marketing channels (Anderson, 2007). After subtracting marketing costs, producers may receive higher per unit revenue and retain a greater share of the retail price. This may be especially important to small producers, many of whom rely exclusively on direct sales outlets (Low and Vogel, 2011).

Peer-reviewed case studies have found that consumers perceive items at farmers' markets to be lower, or more reasonably, priced and of higher quality than prices at supermarkets (Brown, 2003; Wolf et al., 2005). Others have found participants in Federal nutrition programs that promote purchases from direct marketing venues (e.g., Farmers' Market Nutrition Program, Senior Farmers' Market Nutrition Program) perceive quality of produce to be as good (or better), and/or prices to be lower, at the farmers' market compared to their grocery store (McCormack et al., 2010). Media coverage also reflects inconsistency in how farmers' market prices compare to supermarkets (Ruth-McSwain, 2012).

Analyses of prices at direct sales outlets have been limited and have focused on specific geographic areas. Six case studies were conducted in various states, including California, North Carolina, Iowa, Vermont, Oklahoma, and Texas in select months of a particular year. These studies typically compare farmers' market prices to prices 
collected at grocery stores located within short proximity. Sommer et al. (1980) found price savings for fruits and vegetables at farmers' markets in California to be 39 percent and 37 percent, respectively, in the summer and fall of 1979.

More recently, a few additional studies have emerged (Oakley and Appel, 2006; Pirog and McCann, 2009; Claro, 2011; McGuirt et al. (2011); Long et al., 2013). When market basket comparisons are made, farmers' market prices are often found to be lower. For example, McGuirt et al. (2011) compare summertime prices of 230 produce items in 12 North Carolina counties and find an average price savings of 18 percent at the farmers' markets. However, it is difficult to generalize results for individual items. Claro (2011), for instance, compares the price of 14 produce items during July and August in Vermont. The average price for six items at the farmers' markets was found to be statistically significantly higher than the average price at corresponding grocery stores, while the average price at farmers' markets was statistically significantly lower for two items.

There is currently little retail scanner data for local food and no centralized point-of-sale system in which all sales transactions are recorded at direct sales outlets so that a comprehensive analysis of local food prices can be conducted. In this study, we use a nationally representative sample of households and information about their retail food purchases in 2006 to compare prices at direct sales outlets and retail food stores. A hedonic regression model is estimated for fresh tomatoes and apples in the Mid-Atlantic region of the United States. Fresh fruits and vegetable items account for most direct sales to consumers (Low and Vogel, 2011). Results indicate the magnitude of price differences between direct sales outlets, grocery stores, and supercenters across seasons and within different subregions of the Mid-Atlantic region.

\section{DATA SOURCE}

This study uses the 2006 Nielsen Homescan panel data to estimate average fresh tomato and apple prices at various outlets within the Mid-Atlantic region, which includes Delaware, Washington DC, Maryland, New Jersey, Pennsylvania, Virginia, and West Virginia. To our knowledge, there are no studies using a nationally representative survey of households to compare produce prices at direct marketing outlets with prices at other retail stores within a specific geographic region of the United States. The Homescan panel consists of representative U.S. households that provide weekly reports of food purchased for at-home consumption from various retail outlets in at least 10 months of the year. For all purchases, a household records information by scanning the UPC or a designated code for nonUPC, random-weight products (e.g., fresh fruits and vegetables, bakery products produced and packaged in the store, meat products cut and packaged in the store). Purchase data include the purchase date, quantities, expenditures, product attributes, marketing channel or retailer type (grocery stores, supercenters, warehouse clubs, drug stores, mass merchandisers, convenience stores, health food stores, and "all other" retailers), store name, and household demographic data. About 32,000 households record their UPC-labeled items, and 8,000 randomly selected households, referred to as the Fresh Foods panel, also record random-weight products.

In 2007, Nielsen replaced the Fresh Foods Panel with the Total Sample View, which no longer contains details on the random-weight items. Specifically, after 2006, item characteristics and the quantity purchased are no longer recorded.

Because purchases from direct marketing outlets would not have UPCs, they would likely be recorded only through the random-weight collection methodology. For this reason, our analysis includes only products purchased as random-weight items in 2006. According to Nielsen, panelists would likely use the store name "fruit stand," which is included in the "all other" retailer type, to record purchases from direct sales outlets including farmers markets, roadside fruit stands, on-farm sales, and other direct sales outlets (Nielsen, 2009).

While we are able to identify sales from direct marketing outlets, we are unable to verify that the items sold at direct marketing outlets are actually local. For example, some fruit stands may carry both locally grown produce and imported produce, which is sold in order to provide their customers with a one-stop shopping experience. Sales of non-local items at direct sales outlets may be more prevalent in the winter months, especially for produce with a short storage period. In case studies, analysts are better able to distinguish between locally sourced versus non-local produce at direct marketing outlets. For example, Sommer et al. (1980) restricted their price comparisons only to 
certified farmers' markets to provide some assurance that vendors were marketing their own produce. In addition, unlike case studies, we compare prices at direct sales outlets to those at retail food stores over a much broader geographic area rather than stores located near the direct store outlet.

Prices (net of promotional and sales discounts) of tomatoes and apples are computed by dividing total expenditure by quantity purchased (e.g., Huang and Lin, 2007; Lin et al., 2008). Fresh tomatoes and apples are chosen because they are among the most popular random-weight produce items purchased by the Nielsen Homescan panelists in terms of both purchase frequency and expenditures.

\section{MODELING PRICE DIFFERENCES BETWEEN DIRECT MARKETING VENUES AND OTHER RETAIL OUTLETS}

In this paper, we utilize the hedonic method to estimate the implicit value of produce items at direct sales outlets. The underlying assumption of the hedonic model is that utility is derived from $\mathrm{n}$ characteristics of products, $\mathrm{z}=\left(\mathrm{z}_{1}, \mathrm{z}_{2}, \ldots, \mathrm{z}_{\mathrm{n}}\right)$, where $\mathrm{z}_{\mathrm{i}}$ is the amount of the $\mathrm{i}^{\text {th }}$ attribute contained in a product (Rosen, 1974). Each product has a market price and is associated with a specific attribute bundle, $z$, which implies a function relating prices and characteristics:

$$
\mathrm{P}(\mathrm{z})=\mathrm{P}\left(\mathrm{z}_{1}, \ldots, \mathrm{z}_{\mathrm{n}}\right),
$$

This function is the household's and seller's equivalent of a hedonic price regression where the consumer is assumed to maximize utility by choosing a bundle of products and product attributes subject to a budget constraint. The resulting value or bid function for each household indicates the maximum amount these household would be willing to pay for alternative attribute bundles. The producer is assumed to maximize profits by choosing the amount of characteristics and number of units with those characteristics. The resulting offer function indicates the minimum unit price the firm is willing to accept for the attribute bundles produced. $\mathrm{P}(\mathrm{z})$ solves the competitive equilibrium defined by the tangency of the offer and bid functions for attribute bundles, or where $Q^{\mathrm{S}}(z)=Q^{\mathrm{D}}(\mathrm{z})$. Hence, the implicit price of an attribute reflects both consumer willingness to pay and costs of providing that attribute. The marginal or implicit price of each attribute can be estimated based on the observed relationship between the product purchase price and amount of attributes provided by the product.

In addition to type of retail outlet the household purchase was made, the estimated hedonic regression model includes a set of other market attributes (whether product was purchased at a discounted price, season of purchase, and subregion of household residence), product characteristics (organic, brand name, variety, and whether the produce was prepackaged), and socio-demographic factors that characterize the household:

$$
\begin{aligned}
& P_{i t}=\alpha+\beta_{1} \text { Organic }_{i t}+\sum_{j=2}^{4} \beta_{j} \text { RetailOutlet }_{j i t}+\beta_{5} \text { Discount }_{i t} \\
& +\sum_{j=6}^{8} \beta_{j} \text { Season }_{j i t}+\sum_{j=9}^{10} \beta_{j} \text { Subregion }_{j i t}+\beta_{11} \text { Prepack }_{i t}+\sum_{j=12}^{16} \beta_{j} \text { Variety }_{j i t} \\
& +\sum_{j=17}^{20} \beta_{j} \text { Brand }_{j i t}+\beta_{21} \text { Income }_{i t}+\beta_{22} \text { Femalehd }_{i t}+\sum_{j=23}^{24} \beta_{j} \text { Age }_{j i t} \\
& +\sum_{j=25}^{27} \beta_{j} \text { Race }_{j i t}+\beta_{28} \text { Hispanic }_{i t}+\beta_{29} \text { Child }_{i t} \\
& +\sum_{j=30}^{32} \beta_{j} \text { RetailOutlet }_{j i t} \times \text { Income }_{i t}+\sum_{j=2}^{4} \sum_{k=6}^{8} \beta_{j, k} \text { RetailOutlet }_{j i t} \times \text { Season }_{k i t} \\
& +\sum_{j=2}^{4} \sum_{k=9}^{10} \beta_{j,} \text { RetailOutlet }_{j i t} \times \text { Subregion }_{k i t} \\
& +\sum_{j=6}^{8} \sum_{k=9}^{10} \beta_{j,} \text { Season }_{j i t} \times \text { Subregion }_{k i t}+e_{i t}
\end{aligned}
$$

where $P_{i t}$ is price paid by the $\mathrm{i}^{\text {th }}$ household at time $\mathrm{t}$. All variables included in the regression model are defined in Table 1. 
We compare produce prices at direct sales outlets, grocery stores, and supercenters, which are large stores that offer both department store items and a full range of grocery products. Grocery stores account for over 81 percent of fresh tomatoes and apples purchased. However, since Wal-Mart opened its first supercenter in 1988, the growth in supercenters has been one of the most notable changes occurring in U.S. food retailing (Volpe et al., 2013). Supercenter prices have been found to be significantly lower than supermarket prices for comparable products (Volpe et al., 2013). For example, Volpe and Lavoie (2008) estimated average prices to be 14 to 23 percent lower at supercenters compared to supermarkets for national brand products across six major departments.

Previous studies have suggested that seasonality may play a role in differences found in prices at farmers' markets and supermarkets (McGuirt et al., 2011; Pirog and McCann, 2009). To account for possible seasonal and geographic variation in produce price differentials at the different retail outlet types, interaction terms between outlet type and season and outlet type and subregion were also added. Three subregions were compared within the MidAtlantic region: Pennsylvania; Virginia/West Virgina/Washington DC; and Maryland/Delaware/New Jersey. Since the subregion may matter for the seasonal aspect, interaction terms between subregion and season were also included.

Traditionally, hedonic models contain only product and market characteristics. However, we also include demographic variables since they may also affect consumer willingness to pay for a certain product (Huang and Lin, 2007). Higher-income households are expected to pay a higher price since they are more likely to purchase higher quality products, or shop retail outlets offering more services or located in high rent areas (Lin et al., 2008; Huang and Lin, 2007). For this reason, we also include an interaction term between income and type of retail outlet. Younger and white households have generally been found to pay higher prices for produce. Mixed results have been found for presence of a child (Huang and Lin, 2007).

Economic theory provides little guidance regarding the choice of functional form of the hedonic model. Hence, it is essentially an empirical issue. Given that nearly all explanatory variables are dummy variables, the choice of functional form is limited. Based on Box-Cox specification tests, we chose the semi-log functional form over the linear model. ${ }^{1}$ In this case, the log of price serves as the dependent variable in equation 2.

Since the Homescan data may contain multiple observations from the same household, error terms are not likely to be independent, which leads to misleading statistical tests using ordinary least squares (OLS) (Lin et al., 2008; Zhang et al., 2009). For this reason, we use the generalized estimating equations (GEE) method to model correlated data. ${ }^{2}$ The resulting parameter estimates are the same as OLS, assuming that observations are independent between households and correlated within households (i.e., an independent working correlation matrix specification) (Horton and Lipsitz, 1999). However, the variance-covariance matrix of the estimates is adjusted to account for potential downward bias in standard errors and inflated statistical significance of parameter estimates. Our approach also yields consistent estimates of the covariance matrix of parameter estimates in the presence of heteroskedastic errors (Kauermann and Carroll, 2001).

Seasonal and subregional prices at the various retail outlets are estimated by rewriting equation 2 as $\ln \left(\mathrm{P}_{\mathrm{it}}\right)$ $=\beta \mathrm{X}_{\mathrm{it}}+\mathrm{e}_{\mathrm{it}}$, where $\beta$ is a vector of coefficients and $\mathrm{X}_{\mathrm{it}}$ is a vector of corresponding explanatory variables. The expected value of price for a product with characteristics $X_{1}$ is:

$$
\mathrm{E}(\mathrm{P})=\exp \left[\beta \mathrm{X}_{1}+0.5 \sigma^{2}\right]
$$

where $\sigma^{2}$ is the variance of the error term (Oczkowski, 1994).

\footnotetext{
${ }^{1}$ The PROC QLIM procedure in SAS 9.2 was used to estimate the Box-Cox parameters.

${ }^{2}$ The PROC GENMOD procedure in SAS 9.2 is used to fit the GEEs.
} 
Table 1. Definition of variables used in the hedonic models

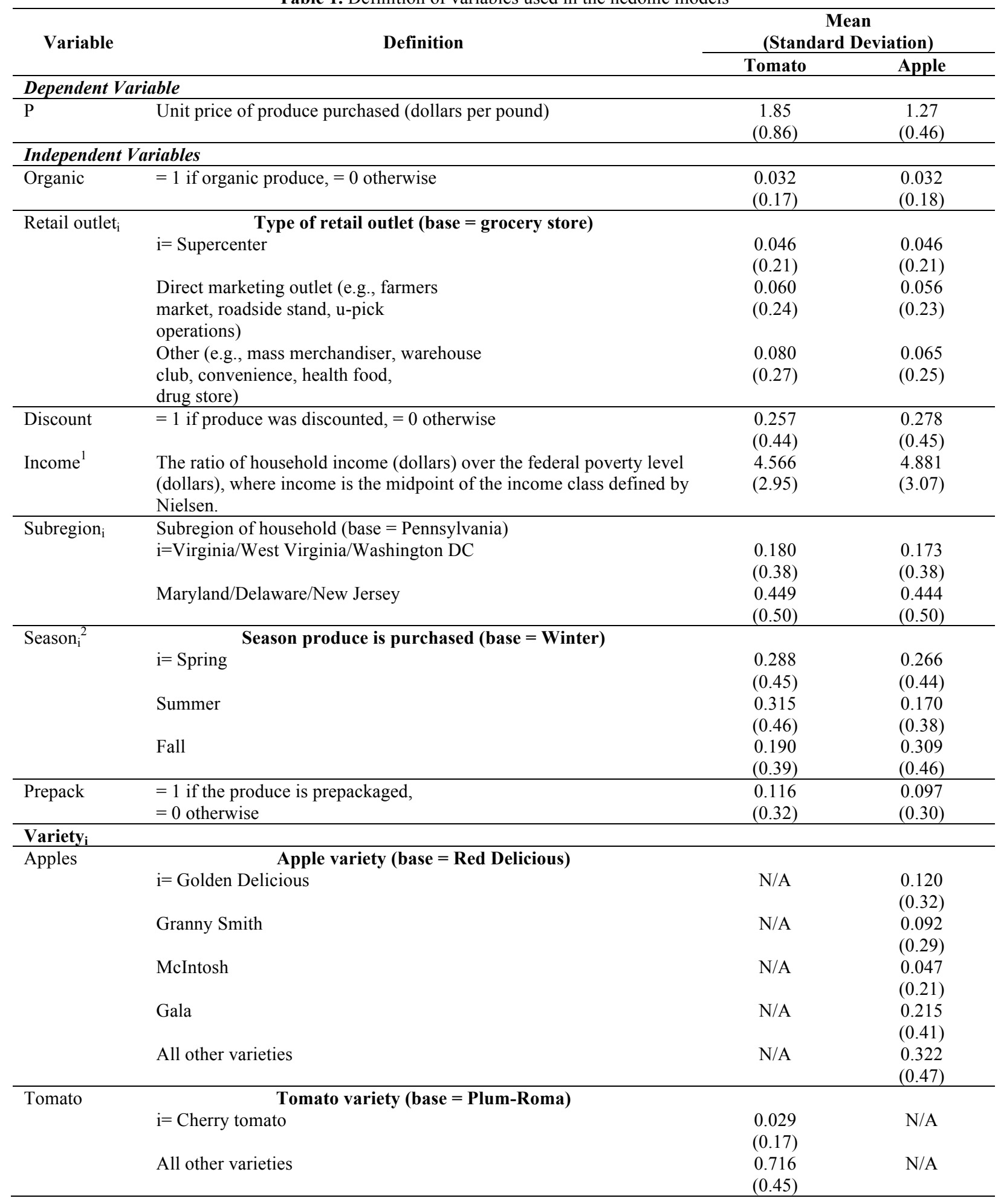


(Table 1 continued)

\begin{tabular}{|c|c|c|c|}
\hline \multirow[t]{2}{*}{ Variable } & \multirow[t]{2}{*}{ Definition } & \multicolumn{2}{|c|}{$\begin{array}{c}\text { Mean } \\
\text { (Standard Deviation) }\end{array}$} \\
\hline & & Tomato & Apple \\
\hline \multirow[t]{8}{*}{ Brand $_{i}^{3}$} & Brand name of produce item $($ base $=$ no brand) & & \\
\hline & $\mathrm{i}=\operatorname{Brand}_{1}$ & $\begin{array}{l}0.006 \\
(0.08)\end{array}$ & $\begin{array}{l}0.063 \\
(0.24)\end{array}$ \\
\hline & Brand $_{2}$ & 0.002 & 0.016 \\
\hline & & $(0.05)$ & $(0.12)$ \\
\hline & Brand $_{3}$ & 0.000 & 0.002 \\
\hline & & $(0.01)$ & $(0.04)$ \\
\hline & Brand $_{o}$ (all other brand names) & 0.188 & 0.231 \\
\hline & & $(0.39)$ & $(0.42)$ \\
\hline \multirow[t]{2}{*}{ Femalehd } & $=1$ if there is a female head of household, & 0.220 & 0.217 \\
\hline & $=0$ otherwise & $(0.41)$ & $(0.41)$ \\
\hline \multirow[t]{5}{*}{ Age $_{i}$} & Age of male or female household head (base $=40$ to 64 years old) & & \\
\hline & $\mathrm{i}=$ Less than 40 years old & 0.105 & 0.143 \\
\hline & & $(0.31)$ & $(0.35)$ \\
\hline & 65 years old or older & 0.355 & 0.296 \\
\hline & & $(0.48)$ & $(0.46)$ \\
\hline \multirow[t]{7}{*}{ Race $_{i}^{4}$} & Race of household head (base $=$ white $)$ & & \\
\hline & $\mathrm{i}=$ Black & 0.116 & 0.110 \\
\hline & & $(0.32)$ & $(0.31)$ \\
\hline & Oriental & 0.023 & 0.030 \\
\hline & & $(0.15)$ & $(0.17)$ \\
\hline & Other & 0.025 & 0.020 \\
\hline & & $(0.16)$ & $(0.14)$ \\
\hline \multirow[t]{2}{*}{ Hispanic $^{4}$} & $=1$ if household head is Hispanic, & 0.035 & 0.033 \\
\hline & $=0$ otherwise & $(0.18)$ & $(0.18)$ \\
\hline \multirow[t]{2}{*}{ Child } & $=1$ if household includes children under 18 , & 0.196 & 0.274 \\
\hline & $=0$ otherwise & $(0.40)$ & $(0.45)$ \\
\hline \multicolumn{2}{|c|}{$\begin{array}{l}\text { Number of } \\
\text { observations }\end{array}$} & 8,914 & 10,469 \\
\hline \multicolumn{4}{|c|}{$\mathrm{N} / \mathrm{A}=$ Not applicable. } \\
\hline \multirow{4}{*}{\multicolumn{4}{|c|}{$\begin{array}{l}{ }^{1} \text { The midpoint of household income for } 19 \text { income classes. Income was divided by the poverty guideline for households of different } \\
\text { sizes (U.S. Department of Health and Human Services) to account for household size in the income measure. } \\
\text { 2Winter months are December, January, and February; Spring months are March, April, and May; Summer months are June, July, and } \\
\text { August; Fall months are September, October, and November (Glossary of Meteorology, } 2^{\text {nd }} \text { edition, American Meteorological } \\
\text { Society, 2012). }\end{array}$}} \\
\hline & & & \\
\hline & & & \\
\hline & & & \\
\hline \multicolumn{4}{|c|}{${ }^{4}$ Race and Hispanic variables are based on categorizations by Nielsen. } \\
\hline
\end{tabular}

\section{RESULTS AND DISCUSSION}

Table 2 reports results from the estimation of equation 2 . The adjusted $R^{2}$ is nearly identical for tomatoes and apples, 0.300 and 0.302 , respectively. The relatively low values do not indicate poor model fit and are typical with cross-sectional data (Lin et al., 2008).

The estimated coefficient associated with direct sales outlets and supercenters is negative and statistically significant at the 5 percent level or lower. Hence prices are estimated to be lower at direct sales outlets and supercenters compared to grocery stores. Price discounts at direct sales outlets compared to those found at grocery stores are larger than those found at supercenters.

Most other variables were also highly statistically significant. The organic, discount, and income variables all had the expected sign. Households paid a premium for organic produce, and those with higher incomes paid a higher price, except for tomatoes purchased at direct sales outlets. The statistically significant and negative interaction term between income and direct sales outlet suggests that income had no effect on prices paid for tomatoes at these venues. Prepackaged fresh produce was purchased at a lower price compared to loose produce. 
Prices also varied by season, brand, variety, presence of a female head of household, and race. White households paid more for apples and tomatoes compared to oriental households. Younger households paid the most for apples, while older households paid the least. There was little subregional variation in prices paid with the exception of tomatoes in the Maryland/Delaware/New Jersey subregion, which sold at the lowest price. Statistically significant interaction terms between season and subregion suggests that in the Maryland/Delaware/New Jersey subregion, tomato prices were higher in the spring, while apples prices were highest in the summer and spring in the Virginia/West Virginia/Washington DC subregion.

Seasonal produce prices at grocery stores, direct sales outlets, and supercenters are estimated using equation 3. Variables other than outlet type and season are evaluated at their sample mean. A statistically significant interaction term between store outlet type and season of purchase suggests that seasonal differences exist in percentage price discounts.

Prices at both direct sales outlets and supercenters are estimated to be lower than prices at grocery stores in all seasons (Table 3). The average tomato price discount at direct sales outlets as a share of the grocery store price is estimated to be lowest in the summer ( 31 percent) when grocery store prices are lowest. The discount is greatest in the winter ( 42 percent) when supplies are more limited and store prices are higher.

Tomato prices are lower at direct sales outlets compared to supercenters throughout the year. The relatively large price discounts at direct sales outlets may reflect price competition between vendors, and farmers who reduce their prices in order to sell all of their produce (Silva et al., 2014; Griffin and Frongillo, 2003). In addition, with few barriers, the threat of new entrants into farmers' markets is high (Connell and Hergesheimer, 2011).

For apples, prices at direct sales outlets are lowest in the spring. Percentage price discounts at direct sales outlets compared to grocery stores are smaller than those for tomatoes and comparable to discounts found at supercenters. Price discounts at both direct sales outlets and supercenters compared to grocery stores are 13 percent in the winter, and exhibit no statistically significant difference across seasons as indicated by the insignificant interaction terms.

Subregional produce prices are similarly estimated using equation 3. Across all regions, produce at direct sales outlets and supercenters sell at a discount compared to grocery stores (Table 4). For tomatoes, percentage price discounts at direct sales outlets are larger than those found at supercenters and exhibit some subregional variation. Direct sales price discounts are estimated to be smallest in the Virginia/West Virginia/Washington DC subregion (36 percent).

Apple price discounts at direct sales outlets are considerably smaller than those found for tomatoes. Supercenter prices are also competitive with those at direct sales outlets. Prices at both outlets are approximately 13 percent lower than grocery store prices in Pennsylvania. There is no statistically significant difference in most discounts at direct sales outlets and supercenters in the other two subregions compared to Pennsylvania, as indicated by the insignificant interaction terms. The only exception is in the Maryland/Delaware/New Jersey subregion, where households paid markedly lower prices for apples at direct sales outlets. 
Table 2. Hedonic log-linear model coefficient estimates

\begin{tabular}{|c|c|c|}
\hline Variable & Tomato & Apple \\
\hline Constant & 0.655 & 0.179 \\
\hline \multicolumn{3}{|l|}{ Outlet (base $=$ grocery store) } \\
\hline Supercenter & $-0.188 * * *$ & $-0.108 * * *$ \\
\hline Direct sales & $-0.472 * * *$ & $-0.154 * *$ \\
\hline Other & $-0.397 * * *$ & $-0.295 * * *$ \\
\hline \multicolumn{3}{|l|}{ Season (base $=$ Winter) } \\
\hline Spring & $-0.221 * * *$ & $-0.032 * *$ \\
\hline Summer & $-0.325 * * *$ & $0.083 * * *$ \\
\hline Fall & -0.038 & 0.004 \\
\hline Supercenter $\times$ Spring & $-0.086^{*}$ & 0.018 \\
\hline Supercenter $\times$ Summer & 0.076 & -0.008 \\
\hline Supercenter $\times$ Fall & 0.002 & 0.049 \\
\hline Direct sales $\times$ Spring & $0.106^{*}$ & 0.006 \\
\hline Direct sales $\times$ Summer & $0.185 * * *$ & -0.054 \\
\hline Direct sales $\times$ Fall & 0.076 & 0.066 \\
\hline Other $\times$ Spring & 0.018 & 0.009 \\
\hline Other $\times$ Summer & 0.052 & -0.052 \\
\hline Other $\times$ Fall & 0.017 & 0.040 \\
\hline \multicolumn{3}{|l|}{ Subregion (base $=$ Pennsylvania) } \\
\hline Subregion1 (Virginia, West Virginia, Washington DC) & -0.017 & -0.006 \\
\hline Subregion2 (Delaware, New Jersey, Maryland) & $-0.056^{*}$ & -0.008 \\
\hline Supercenter $\times$ Subregion 1 & 0.024 & 0.013 \\
\hline Supercenter $\times$ Subregion 2 & 0.074 & 0.010 \\
\hline Direct sales $\times$ Subregion 1 & $0.259 * * *$ & -0.049 \\
\hline Direct sales $\times$ Subregion 2 & -0.004 & $-0.195 * *$ \\
\hline Other $\times$ Subregion 1 & -0.043 & $-0.131 * *$ \\
\hline Other $\times$ Subregion 2 & 0.021 & 0.051 \\
\hline Spring $\times$ Subregion 1 & 0.055 & $0.055^{* *}$ \\
\hline Spring $\times$ Subregion 2 & $0.055^{*}$ & 0.000 \\
\hline Summer $\times$ Subregion 1 & 0.046 & $0.059 * *$ \\
\hline Summer $\times$ Subregion 2 & 0.046 & 0.005 \\
\hline Fall $\times$ Subregion 1 & -0.002 & 0.011 \\
\hline Fall $\times$ Subregion 2 & -0.003 & 0.011 \\
\hline Organic & $0.142 * * *$ & $0.204 * * *$ \\
\hline Discount & $-0.253 * * *$ & $-0.249 * * *$ \\
\hline Prepack & $-0.287 * * *$ & $-0.240 * * *$ \\
\hline \multicolumn{3}{|l|}{ Variety } \\
\hline \multicolumn{3}{|l|}{ Tomato (base $=$ Plum-Roma) } \\
\hline Cherry & $0.248 * * *$ & N/A \\
\hline Other & $0.125 * * *$ & N/A \\
\hline \multicolumn{3}{|l|}{ Apples (base $=$ Red Delicious) } \\
\hline Golden Delicious & N/A & $0.031 * *$ \\
\hline Granny Smith & $\mathrm{N} / \mathrm{A}$ & $0.133 * * *$ \\
\hline McIntosh & N/A & -0.010 \\
\hline Gala & $\mathrm{N} / \mathrm{A}$ & $0.123^{* * *}$ \\
\hline Other & $\mathrm{N} / \mathrm{A}$ & $0.072 * * *$ \\
\hline \multicolumn{3}{|l|}{ Brand (base $=$ no brand) } \\
\hline Brand $_{1}$ & $0.162 * * *$ & $0.039 * *$ \\
\hline Brand $_{2}$ & 0.059 & 0.040 \\
\hline Brand $_{3}$ & $0.717 * * *$ & $-0.356^{* * *}$ \\
\hline Brand $_{o}$ & $0.096^{* * *}$ & $0.039 * * *$ \\
\hline Income & $0.018 * * *$ & $0.009 * * *$ \\
\hline Supercenter $\times$ Income & -0.008 & -0.006 \\
\hline Direct sales $\times$ Income & $-0.018 * *$ & 0.004 \\
\hline Other $\times$ Income & -0.010 & 0.004 \\
\hline
\end{tabular}




\begin{tabular}{lcc}
\hline \multicolumn{1}{c}{ Variable } & Tomato & Apple \\
\hline Femalehd & $0.049^{* *}$ & $0.030^{*}$ \\
Age (base $=$ male or female head is 40 to 64 years old) & & $0.060^{* * *}$ \\
$\quad<40$ years & 0.033 & $-0.043^{* *}$ \\
$\quad 65$ years old or older & -0.033 & 0.002 \\
\hline Race (base = household head is white ) & $-0.062^{* * *}$ & $-0.075^{*}$ \\
$\quad$ Black & $-0.188^{* * *}$ & -0.013 \\
Oriental & $-0.190^{* * *}$ & $-0.159^{* * *}$ \\
Other & -0.087 & 0.007 \\
Hispanic & $0.068^{* * *}$ & 0.302 \\
Child & 0.300 & \\
\hline Adjusted $\mathrm{R}^{2}$ &
\end{tabular}

\section{CONCLUSIONS}

Our analysis indicates that average prices for fresh tomatoes and apples in the Mid-Atlantic region were significantly lower at direct-to-consumer venues compared to grocery stores. For tomatoes, prices at direct sales outlets were also found to be lower than at supercenters throughout the year and across all subregions. Apple prices at direct sales outlets and supercenters were comparable in all seasons, and in two of the three subregions. Prices at direct sales outlets were significantly lower than supercenter prices in the Maryland/Delaware/New Jersey subregion. These results are consistent with smaller case studies that found it difficult to generalize results for individual items and different geographic locations. Further research is warranted to understand the differences found in relative price comparisons between direct sales outlets and retail stores across individuals. Because we also found some difference in relative price comparisons across subregions, it may be important to consider multiple locations in price analyses.

Surveys that estimate consumers' willingness to pay for locally produced food based on their responses in a hypothetical context suggest that consumers would be willing to pay a premium for locally-produced foods (Carpio and Isengildina-Massa, 2009; James et al., 2009; Darby et al., 2008; Giraud et al., 2005; Hinson and Bruchhaus, 2005; Loureiro and Hine, 2002). The estimated price discounts at direct sales outlets compared to grocery stores and, in some cases, supercenters suggests that consumer attitudes may fail to translate into actual purchases of local foods at higher prices. This conclusion is corroborated by Xu et al. (2015) who used retail scanner data at grocery stores in Honolulu to estimate the premium for "local" fresh packaged lettuce. Based on actual transaction data, they found no evidence of a price premium. Actual purchase behavior may reflect inconvenience and lack of one-stop shopping, which has been found to be an important barrier to shopping at direct sales outlets (Chambers et al., 2007).

Price setting strategies at direct-to-consumer venues also warrant further investigation. Competition among farmers' market vendors may lead them to undervalue their products. Producers may benefit from education programs designed to improve their pricing strategies to better reflect the value of their products. Alternatively, price discounting may serve as a strategy for increasing market share (Xu et al., 2015). While consumers expect higher quality from direct marketing outlets, they are also sensitive to price and value (Curtis et al., 2014). 
Table 3. Predicted prices for fresh tomatoes and apples by season and type of retail outlet, 2006 (dollars per pound) ${ }^{1}$

\begin{tabular}{|c|c|c|c|c|}
\hline Outlet type & Winter & Spring & Summer & Fall \\
\hline & \multicolumn{4}{|c|}{ Tomatoes } \\
\hline Grocery store & $\$ 2.24$ & $\$ 1.81$ & $\$ 1.63$ & $\$ 2.16$ \\
\hline Supercenter & $\$ 1.79$ & $\$ 1.33$ & $\$ 1.41$ & $\$ 1.73$ \\
\hline Direct sales & $\$ 1.29$ & $\$ 1.16$ & $\$ 1.13$ & $\$ 1.34$ \\
\hline \multicolumn{5}{|l|}{ Percentage discount compared to grocery store } \\
\hline Supercenter & -20.11 & -26.66 & $-13.77^{2}$ & $-19.99^{2}$ \\
\hline Direct sales & -42.36 & -35.90 & -30.67 & $-37.79^{2}$ \\
\hline & \multicolumn{4}{|c|}{ Apples $^{3}$} \\
\hline Grocery store & $\$ 1.28$ & $\$ 1.25$ & $\$ 1.40$ & $\$ 1.29$ \\
\hline Supercenter & $\$ 1.12$ & $\$ 1.10$ & $\$ 1.21$ & $\$ 1.18$ \\
\hline Direct sales & $\$ 1.12$ & $\$ 1.09$ & $\$ 1.15$ & $\$ 1.20$ \\
\hline Percentage discount compared to grocery store & & & & \\
\hline Supercenter & -12.84 & -11.29 & -13.56 & -8.46 \\
\hline Direct sales & -13.03 & -12.53 & -17.63 & -7.13 \\
\hline
\end{tabular}

\footnotetext{
${ }^{\mathrm{I}}$ Price estimates are obtained using equation 3. Variables other than season and outlet type are evaluated at the sample mean.

${ }^{2}$ Percentage price discount is not statistically significantly different from the discount in the winter.

${ }^{3}$ For apples, the percentage price discount in the non-winter seasons are not statistically significantly different from those found in the winter.
}

Table 4. Predicted prices for fresh tomatoes and apples by subregion and type of retail outlet, 2006 (dollars per pound) ${ }^{1}$

\begin{tabular}{|c|c|c|c|}
\hline Outlet type & Pennsylvania & $\begin{array}{l}\text { Virginia, West } \\
\text { Virginia, } \\
\text { Washington, DC }\end{array}$ & $\begin{array}{l}\text { Maryland, Delaware, } \\
\text { New Jersey }\end{array}$ \\
\hline & \multicolumn{3}{|c|}{ Tomatoes } \\
\hline Grocery store & $\$ 1.94$ & $\$ 1.92$ & $\$ 1.86$ \\
\hline Supercenter & $\$ 1.55$ & $\$ 1.56$ & $\$ 1.59$ \\
\hline Direct sales & $\$ 1.12$ & $\$ 1.44$ & $\$ 1.07$ \\
\hline $\begin{array}{l}\text { Percentage discount compared to grocery store: } \\
\text { Supercenter } \\
\text { Direct sales }\end{array}$ & $\begin{array}{l}-20.25 \\
-42.03\end{array}$ & $\begin{array}{l}-24.90^{2} \\
-35.90\end{array}$ & $\begin{array}{l}-14.16^{2} \\
-42.29^{2}\end{array}$ \\
\hline & \multicolumn{3}{|c|}{ Apples } \\
\hline Grocery store & $\$ 1.30$ & $\$ 1.30$ & $\$ 1.29$ \\
\hline Supercenter & $\$ 1.13$ & $\$ 1.14$ & $\$ 1.14$ \\
\hline Direct sales & $\$ 1.13$ & $\$ 1.08$ & $\$ 0.93$ \\
\hline $\begin{array}{l}\text { Percentage discount compared to grocery store: } \\
\text { Supercenter } \\
\text { Direct sales }\end{array}$ & $\begin{array}{l}-12.81 \\
-12.55\end{array}$ & $\begin{array}{l}-11.66^{2} \\
-16.75^{2}\end{array}$ & $\begin{array}{l}-11.96^{2} \\
-28.05\end{array}$ \\
\hline
\end{tabular}

${ }^{\mathrm{l}}$ Price estimates are obtained using equation 3. Variables other than subregion and outlet type are evaluated at the sample mean.

${ }^{2}$ Percentage price discount is not statistically significantly different from the discount in Pennsylvania.

\section{AUTHOR INFORMATION}

Steve Martinez is an agricultural economist with the Economic Research Service, U.S. Department of Agriculture, Washington DC. Views expressed are those of the authors and not necessarily those of the U.S. Department of Agriculture.

\section{REFERENCES}

Anderson, M.D. 2007. "The Case for Local and Regional Food Marketing," Farm and Food Policy Project issue brief. Washington, DC: Northeast- Midwest Institute.

Brown, C. 2003. "Consumers' Preferences for Locally Produced Food: A Study in Southeast Missouri," American Journal of Alternative Agriculture, Vol. 18, pp. 213-224.

Carpio, C.E., and O. Isengildina-Massa. 2009. "Consumer Willingness to Pay for Locally Grown Products: The Case of South Carolina," Agribusiness, Vol. 25, pp. 412-426.

Chambers, S., A. Lobb, L. Butler, K. Harvey, and W.B. Traill. 2007. "Local, National and Imported Foods: A Qualitative Study," Appetite, Vol. 49, pp. 208-213. 
Claro, J. January 2011. "Vermont Farmers’ Markets and Grocery Stores: A Price Comparison.” Northeast Organic Farming Association of Vermont.

Connell, D., and C. Hergesheimer. 2011. Selling at BC's Farmers' Markets: A Guide for New Farmer Vendors. Vancouver, BC: British Columbia Association of Farmers' Markets.

Curtis, K.R., I. Yeager, B. Black, D. Drost, and R. Ward. 2014. "Market and Pricing Potential for Extended Season Fresh Produce Sales: An Intermountain West Example," Journal of Food Distribution Research, Vol. 42: pp. 46-65.

Darby, K., et al. 2008. "Decomposing Local: A Conjoint Analysis of Locally Produced Foods," American Journal of Agricultural Economics, Vol. 90: pp. 476-486.

Desrochers, P., and H. Shimizu. 2012. The Locavore's Dilemma: In Praise of the 10,000-Mile Diet, New York: PublicAffairs.

Gao, Z., M. Swisher, and X. Zhao. 2012. "A New Look at Farmers' Markets: Consumer Knowledge and Loyalty.” HortScience, Vol. 47: pp. 1102-1107.

Giraud, K.L., C.A. Bond, and J.J. Bond. 2005. "Consumer Preferences for Locally Made Specialty Food Products Across Northern New England.” Agricultural and Resource Economics Review, Vol. 34: pp. 204-216.

Griffin, M.R., and E.A. Frongillo. 2003. "Experiences and Perspectives of Farmers From Upstate New York Farmers' Markets," Agriculture and Human Values, Vol. 20: pp. 189-203.

Hardesty, S.D., and P. Leff. 2009. "Determining Marketing Costs and Returns in Alternative Marketing Channels," Renewable Agriculture and Food Systems, Vol. 25: pp. 24-34.

Hinson, Roger A., and Michael N. Bruchhaus. 2005. "Louisiana Strawberries: Consumer Preferences and Retailer Advertising," Journal of Food Distribution Research, Vol. 36: pp. 86-90.

Horton, N.J., and S.R. Lipsitz. 1999. "Review of Software to Fit Generalized Estimating Equation Regression Models," The American Statistician, Vol. 53: pp. 160-169.

Huang, C.L., and B. Lin. 2007. "A Hedonic Analysis of Fresh Tomato Prices among Regional Markets." Review of Agricultural Economics, Vol. 29: pp. 783-800.

James, Jennifer, Bradley Rickard, and William Rossman. 2009. Product Differentiation and Market Segmentation in Applesauce: Using a Choice Experiment to Assess the Value of Organic, Local, and Nutrition Attributes, Working Paper WP 2009-01, Department of Applied Economics and Management, Cornell University, Ithaca, NY.

Kauermann, G., and R.J. Carroll. 2001. "A Note on the Efficiency of Sandwich Covariance Matrix Estimation,” Journal of the American Statistical Association, Vol. 96: pp. 1387-1396.

King, Robert P., et al. 2010. Comparing the Structure, Size, and Performance of Local and Mainstream Food Supply Chains, USDA, Economic Research Service, ERR-99.

Kumcu, A. 2009. "ERS Holdings of Nielsen Homescan Data." USDA, Economic Research Service.

Lin, B., T.A. Smith, and C.L. Huang. 2008. "Organic Premiums of U.S. Fresh Produce.” Renewable Agriculture and Food Systems, Vol. 23: pp. 208-216.

Long, J., M.A. Sounny-Slitine, K. Castles, J. Curran, H. Glaser, E. Hoyer, W. Moore, L. Morse, M. O’Hara, and B. Parafina. 2013. "Toward an Applied Methodology for Price Comparison Studies of Farmers' Markets and Competing Retailers at the Local Scale," Journal of Agriculture, Food Systems, and Community Development, Vol. 3, pp. 95-119.

Loureiro, M.L., and S. Hine. 2002. "Discovering Niche Markets: A Comparison of Consumer Willingness to Pay for Local (Colorado Grown), Organic, and GMO-Free Products," Journal of Agricultural and Applied Economics, Vol. 34, pp. 477-487.

Low, S.A., and S. Vogel. 2011. Direct and Intermediated Marketing of Local Foods in the United States, USDA, Economic Research Service, ERR-128.

McCormack, L.A., M.N. Laska, N.I. Larson, and M. Story. 2010. "Review of the Nutritional Implications of Farmers' Markets and Community Gardens: A Call for Evaluation and Research Efforts," Journal of the American Dietetic Association, Vol. 110, pp. 399-408.

McGuirt, J.T., S.B. Jilcott, H. Liu, and A.S. Ammerman. 2011. "Produce Price Savings for Consumers at Farmers' Markets Compared to Supermarkets in North Carolina," Journal of Hunger and Environmental Nutrition, Vol. 6, pp. 86-98.

Nielsen. 2009. Personal communication, New York, NY, February 19.

Oakley, E., and M. Appel. 2006. "Fresh and Affordable: A Comparison of Farmers' Market and Grocery Store Prices": In Closer to Home: Healthier Food, Farms, and Families in Oklahoma, 
M. McDermott, Ed. Kerr Center for Sustainable Agriculture, Poteau, Oklahoma. Accessed September 28, 2012. $<$ http://www.kerrcenter.com/publications/closer to home/toc.htm $>$.

Oczkowski, E. 1994. “A Hedonic Price Function For Australian Premium Table Wine.” Australian Journal of Agricultural Economics, Vol. 38, pp. 93-110.

Onianwa, O., M. Mojica, G. Wheelock. 2006. "Consumer Characteristics and Views Regarding Farmers Markets: An Examination of On-site Survey Data of Alabama Consumers." Journal of Food Distribution Research, Vol. 37, pp. 119-125.

Pirog, Rich, and Nick McCann. December 2009. "Is Local Food More Expensive?: A Consumer Price Perspective on Local and Non-Local Foods Purchased in Iowa." Leopold Center for Sustainable Agriculture, Ames, IA.

Ragland, E., and D. Tropp. 2009. “USDA National Farmers' market Manager Survey 2006.” Agricultural Marketing Service, USDA. May.

Rosen, S. 1974. "Hedonic Prices and Implicit Markets: Product Differentiation in Pure Competition," Journal of Political Economy, Vol. 82, pp. 34-55.

Ruth-McSwain, A. 2012. "Eating Green: Coverage of the Locavore Movement," Journal of Extension, Vol. 50, Article 5FEA7.

Silva, E., F. Dong, P. Mitchell, and J. Hendrickson. 2014. "Impact of Marketing Channels on Perceptions of Quality of Life and Profitability for Wisconsin's Organic Vegetable Farmers," Renewable Agriculture and Food Systems, May, pp. 1-11.

Sommer, R., M. Wing, and S. Aitkens. 1980. "Price Savings to Consumers at Farmers' Markets," The Journal of Consumer Affairs, Vol. 14, pp. 452-462.

U.S. Department of Agriculture, Agricultural Marketing Service. 2012. Farmers' Market Growth: 1994-2012. Accessed September 2012 at: http://www.ams.usda.gov/AMSv1.0/ams.fetchTemplateData.do?template=TemplateS\&navID=Wholesalea ndFarmersMarkets\&leftNav=WholesaleandFarmersMarkets\&page=WFMFarmersMarketGrowth\&descripti on=Farmers \%20Market $\% 20$ Growth\&acct=frmrdirmkt

U.S. Department of Health and Human Services. The 2006 HHS Poverty Guidelines. Accessed September 2012 at: http://aspe.hhs.gov/poverty/06poverty.shtml

Volpe, R.J., and N. Lavoie. 2008. "The Effect of Wal-Mart Supercenters on Grocery Prices in New England," Applied Economic Perspectives and Policy, Vol. 30, pp. 4-26.

Wolf, M.M., A. Spittler, and J. Ahern. 2005. "A Profile of Farmers' Market Consumers and the Perceived Advantages of Produce Sold at Farmers' Markets," Journal of Food Distribution Research, Vol. 36, pp. 192-201.

Xu, X., M.K. Loke, and P. Leung. 2015. "Is There a Price Premium for Local Food? The Case of the Fresh Lettuce Market in Hawaii," Agricultural and Resource Economics Review, Vol. 44, pp. 110-123.

Zhang, F., J.E. Epperson, C.L. Huang, and J.E. Houston. 2009. "Organic Price Premiums Paid for Fresh Tomatoes and Apples by U.S. Households: Evidence from Nielsen Homescan Data," Journal of Food Distribution Research, Vol. 40, pp. 105-114. 